\title{
Quality conventions in the exported Finnish master's degree programme in teacher education in Indonesia
}

\author{
Henna Juusola ${ }^{1}$ (D) Pekka Räihä ${ }^{2}$
}

Published online: 25 July 2019

(C) The Author(s) 2019

\begin{abstract}
In recent higher education research, quality in education export action has been explored from the perspective of traditional education export countries such as the UK and USA. However, less attention is given to novice education export providers that rely on different educational traditions. In this article, we explore quality of education as it is done in one exported Finnish master's degree programme in teacher education in Indonesia. Our theoretical premise is based on the convention theory that relies on pragmatic sociology. The empirical data consist of 16 semi-structured students' and staff members' interviews gathered between the years 2016 and 2017 in Finland and in Indonesia. The results of this study stress the plurality of the quality factors that indicate the expectations by the students and the staff members, but also the priorities of the providers as to what is essential in exported degree-based education. From the perspective of convention theory, these considerations emphasize that the successful implementation of the exported master's degree programme in teacher education is based on the professional-academic convention (as research-based teacher education) that together with the civic-domestic convention (as societal impact, local traditions and Finnish approach to pedagogy) influenced the content of the educational programme through personal interaction.
\end{abstract}

Keywords Education export · Quality of education · Finnish teacher education · Convention theory $\cdot$ Quality conventions

Henna Juusola

henna.juusola@tuni.fi

Pekka Räihä

pekka.raiha@tuni.fi

1 Faculty of Management and Business, Tampere University, Kalevantie 4, Tampere, Finland

2 Faculty of Education and Culture, Tampere University, Kalevantie 4, Tampere, Finland 


\section{Introduction}

In higher education research, quality in education is typically seen as a subjective, relative and value-laden concept (Harvey and Green 1993) aiming to answer the questions of what is good or valuable (Harvey and Green 1993; Segers and Dochy 1996). Accordingly, quality in the education export context is framed as a multifaceted phenomenon (Altbach and Knight 2007) in which heterogeneity of the actors and diversity of actions can cause information asymmetry and goal-conflicts (Borgos 2013). At the same time, increasing demands to be active in a global knowledge market force higher education institutions (HEIs) to consider quality more and more as fitness-for-use, by emphasizing a users' (i.e. students and clients) approach (Marginson 2006; Silva et al. 2017) and giving more space to international reputation and value-for-money aspects (Marginson 2006).

In this study, quality of education is considered in the context of the Finnish education export phenomenon by giving special attention to one exported Finnish master's degree programme in teacher education in Indonesia that was organized between the years 2016 and 2017. This represents a case example of one of the first commissioned Finnish degree programmes, and thus, it enables researchers to focus on quality as it is done in an early-stage implementation of education export activities by a novice provider without a long tradition of acting in the global educational market. Moreover, this study illustrates the social dynamics in the frame of quality between the Finnish university staff members and Indonesian students, directing the focus on plural conventions as shared sociocultural frames for planning the actions that indicate quality in education (c.f. Diaz-Bone and Salais 2011) and that reinforce common understanding about quality practices (Biggart and Beamish 2003).

In the Finnish context, education export refers to for-profit educational actions that target foreigners either in Finland or abroad (Schatz 2016). While there are other terms, such as transnational education and cross-border education describing a similar phenomenon (Knight 2016), in this study, we prefer to use education export. This will connect our study with the Finnish higher education policy debate while emphasizing the Finnish educational tradition where PISA superiority is based on non-neoliberal logics, on which the education export success story is built (Schatz 2016), even though the educational export phenomenon itself can be considered as academic capitalism (Slaughter and Leslie 1997).

The theoretical framework of this research relies on convention theory. This study aims to identify the internal logics (conventions) that illustrate the quality of education from the perspective of students and staff members of the exported master's programme by focusing on three main research questions: what factors describe the quality of education from the perspective of students and the staff members? What logics (i.e. conventions) steer the identified quality factors? How do these conventions differ, or are the same, among the students and the staff members? The empirical data covers 16 semi-structured interviews conducted in Indonesia and Finland during 2016-2017. This will create a supplementary perspective to consider quality of education in a situation where the national view in Finland on the quality of education and quality assurance stresses the responsibility of HEIs. Also, the Finnish approach to quality assurance is primarily based on the audit, which examines the functionality of the quality assurance system rather than the quality of the education (FINEEC 2015). Thus, this study raises issues related to the implementation of the degree programme, which may not appear in national quality assurance.

This article consists of the following sections: firstly, the quality concept is explored from the perspective of education export. Secondly, the convention theoretical application, the data 
and method are explained. Thirdly, the findings are presented by categorizing the main results by interview group (students and staff), and finally, the findings are summarized and interpreted from the perspective of convention theory.

\section{The quality concept in the context of education export}

In previous education export studies, quality of education has been one of the main concerns from the perspective of culturally bound learning and teaching experiences (Pyvis 2011; Sharp 2017), of students' satisfaction with receiving education and support services (Silva et al. 2017), as well as of jurisdictional conditions set for education export activities in the provider's country of origin and the destination country (Coates and Mahat 2014). In these studies, one of the main conclusions is that cultural context impacts the way quality of learning is experienced by the students (Pyvis 2011). Therefore, a single reference approach is not appropriate for identifying quality of education (Sharp 2017). However, recent research has stressed the importance of setting robust academic standards which apply regardless of where the education is physically located (Sharp 2017), even though the challenges that occur with two conflicting different national quality assurance approaches may still remain (Kinser 2011).

Moreover, commercialisation and market-like behaviour, which are at the core of the education export phenomenon (Slaughter and Leslie 1997), include several implications that may impact the way quality of education, academic standards and quality assurance are organized (Altbach and Knight 2007; Coates and Mahat 2014; Marginson 2006). Firstly, the market-like behaviour of higher education institutions in general is implicitly and explicitly interconnected with the quality concept, reinforcing the global knowledge creation context that is blurring the boundaries of markets, states and public and private goods and the purpose of higher education (Marginson 2006; Slaughter and Rhoades 2004). As an example, the number of new kinds of for-profit forms in the educational sector is increasing (Slaughter and Leslie 1997), some of them owned by public HEIs, some of them owned by private HEIs or both (Altbach and Knight 2007). This highlights the question of transparency in terms of who owns the curriculum, who carries out the teaching and for whom the higher education is accessible (and on what terms) (Coates and Mahat 2014). Also, increasing desire to become one of the winners in the global knowledge market has put more pressure on HEIs to clarify their marketing strategies to better conform to international rankings and competition for fame (Marginson 2006). In this kind of context, academics are required to be able to participate in education export projects at short notice (Juusola and Räihä 2018) and work in the name of efficiency in a certain (often too narrow) timeframe (Bovill et al. 2015). These aspects make the quality of education and quality assurance multidimensional issues, in which the practices and policies of education are developed in parallel in institutional, local, national, and international systems (Coates and Mahat 2014; Marginson 2006).

While previous studies on education export activities would suggest there are challenges in balancing quality of education, academic standards and quality assurance for any HEIs, the quality of education export has not became an issue on the Finnish higher education policy agenda and only little research has been done concerning the quality aspects of Finnish education export. One reason for this may be that education export is a relatively recent phenomenon in Finland. Also, the character of Finnish education export is fragmented, covering different providers from public HEIs to large private companies. Likewise, the national governmental actors improving education export activities represent different 
ministries, such as the Ministry of Education and Culture and the Ministry of Foreign Affairs. A diversified concept with fragmented actors raises questions as to which governmental body could potentially set national criteria and how to assure the quality of Finnish education export in general when the providers are operating at least partly different regimes. On the one hand, these kinds of considerations reflect the vague national description of education export as it currently seems to be. On the other hand, this kind of situation is relatively well recognized in previous higher education studies when they stress the diverse phenomenon of academic capitalism where the boundaries of market, state, international, national and local dimensions are blurring (Marginson 2006; Slaughter and Leslie 1997). Considering previous research studies, but keeping an open mind as to supplementary explanations, this study aims to approach the unresearched Finnish education export phenomenon by stressing the students' and the staff members' perception of quality of education. Thus, one contribution of this study is to increase the understanding of quality, as it is done in one education export project provided by a novice player that has traditionally relied on a non-neoliberal higher education policy.

\section{Theoretical framework}

In this article, we apply convention theory (CT) as a theoretical framework for analysing quality in higher education in the context of Finnish education export. CT claims that conventions as sociocultural frames steer action and decisions in cases of uncertainty (DiazBone and Salais 2011) and provide the principles for justification and evaluation of objects, people and actions (Boltanski and Thévenot 2006). Valuing and testing their worth are judged based on whether they contribute to the common good, which varies depending on the convention in question (Boltanski and Thévenot 2006). The justification and evaluation process from the perspective of CT indicates both legitimation and accountability in public, but also the moral aspect of people, objects or actions (Boltanski and Thévenot 2006; Leemann 2018). Thus, CT invites us to consider plural and contradictory notions of quality in the context of higher education export where analysis needs to account for a different sociocultural context and global trend of commercialisation of higher education. Accordingly, CT enables us to explore practical arrangements of education export activities and the logics behind them in a current setting of the education export phenomenon in Finland.

In CT, worthiness indicates quality; what is of worth in a certain situation reflects the quality of the product or services. Quality of products and services is a relative concept steered by various conventions. Actors dealing with different conventions may have a different level of information concerning quality, and this may cause information asymmetry among actors. (Ponte 2009). Also, quality of products or services can be based on several different conventions, or compromises among several conventions (Boltanski and Thévenot 2006; Ponte 2009).

In this study, CT provides a coherent framework to identify the underlying principles and values that guide the concrete action that aims at good or sufficient outcomes, initiatives or performance. CT also stresses the social dynamics of orders of worth where competing notions of quality are seen as a central feature of quality of education. ${ }^{1}$ This will emphasize the circumstances and social dynamics that refer to education export as a vague phenomenon in

\footnotetext{
${ }^{1}$ The plurality of competing logics is also recognized in the institutional logic approach, though institutional logic does not emphasize the values and objects (e.g. Greenwood et al. 2011; Friedland and Alford 1991.)
} 
which the activities are fragmented and project-based, as currently seems to be the case in Finland. Moreover, the CT perspective stresses the stage where the practices of institutions' quality assurance may not cover all possible situations. In CT, quality assurance (internal and external) can be considered immaterial dispositifs that represent investment in forms (DiazBone and Salais 2011; Thévenot 1984). Investment in forms aims to generalize process or knowledge by putting them in a certain conventional form by disregarding single or optional cases (Blokker and Brighenti 2011). Investment in forms can support coordination and trust among actors, thus enabling them to make action more effective (Diaz-Bone and Salais 2011).

In $\mathrm{CT}$, conventions are based on an underlying higher common principle which offers a commonly understood sphere for action (Boltanski and Thévenot 2006, 138). Conventions are open and negotiable (Ponte 2009); in the same phenomena, several conventions may exist, though some conventions can be more dominant than others (Storper and Salais 1997). In this study, conventions are based on Boltanski and Thévenot's (2006) identification of six conventions using the Storper and Salais (1997) and Boltanski and Chiapello (2005) previous studies in the field of CT. Therefore, our conventional framework includes: inspired world, domestic world, world of fame, civic world, market world, industrial world (Boltanski and Thévenot 2006), intellectual world, interpersonal world (Storper and Salais 1997) and projectoriented world (Boltanski and Chiapello 2005) (see Table 1).

In the inspired convention, inspiration and creativeness are a higher common principle; worthiness can be tested by emotional and adventurous experiences. In the domestic convention, traditions and hierarchy matter, as do trustworthiness and responsibilities. In the fame, convention renown in public is important and thus being visible (in public), matters. In the civic convention, collectiveness is seen as a higher common principle; worthiness is based on solidarity and collective interest. In the market, convention competition represents the higher common principle; worthiness depends on how desirable the goods or services are. In the industrial convention, efficiency is the highest common principle; productivity and functionality can be tested by relying on objective measurable evidence (such as standards). (Boltanski and Thévenot 2006; Ponte 2009.) The intellectual convention aims to develop something new or benefit already existing knowledge by applying generally agreed methods; worthiness is based on the novelty and therefore the outcome cannot be entirely ensured beforehand (Storper and Salais 1997.) In this research, intellectual convention has been divided into academic convention (stressing the scientific premises) and professional convention (stressing expertise) as it allows us to have more coherent analytical premises for this study. In the interpersonal

Table 1 Summary of the conventions (c.f. Boltanski and Chiapello 2005; Boltanski and Thévenot 2006; Storper and Salais 1997)

\begin{tabular}{ll}
\hline Convention & Higher common principle \\
\hline Inspired & Creativeness \\
Domestic & Responsibility, traditions \\
Fame & Recognition; renown in public \\
Civic & Collectiveness \\
Market & Competition \\
Industrial & Effectiveness, productivity \\
Academic & Creating new knowledge based on scientific standards \\
Professional & Knowledge and competence based on expertise \\
Interpersonal & Personal relations \\
Project-oriented & Networking \\
\hline
\end{tabular}


convention, everything is personal, and the actors know each other. Therefore, personal interaction indicates the higher common principle (Storper and Salais 1997). The projectoriented convention covers networks and short-term activities; the worthiness is in gaining a multiple amount of different projects; the more they differ, the more valuable they are (Boltanski and Chiapello 2005).

This research CT offers a coherent approach to explore quality in higher education in the context of Finnish education export. This will set a certain starting point for the research. Firstly, quality in higher education is formed primarily in social interaction and the quality is framed in relation to some other activities. Secondly, quality in higher education is not unquestionably stable, nor can it be self-evidently established beforehand, as the qualities describing quality are based on conventions that vary depending on the situation, which may not be known beforehand. In cases where conventions are generalized in investment in forms, they are often taken for granted, though a new situation or new action can 'disturb' the stable situation leading to reconstruction of the earlier convention (Thévenot 1984).

\section{Empirical case, data and method}

In this article, we stress the factors that describe the quality of education in the exported master's degree programme in teacher education from the perspective of students and staff members. This provides a comparative approach to consider the notions relating to quality among the different stakeholders (students and staff members), which implicitly includes the comparison between the exporter country's (Finland) and user country's (Indonesia) perspective on the purpose and content of the master's degree programmes in teacher education. Also, factors describing quality and the logics (i.e. conventions) behind them illustrate the nationally bounded approach to quality assurance as national quality assurance is not currently targeted in the programme-level accreditation and there are no (national) quality criteria for education export implementations. In this study, factors describing quality refer to the qualities, the distinguishing characteristics of the exported progamme on the microlevel. The factors are interpreted during the data analysis in a conventional theoretical framework, as it enabled to consider the plural and competing notions of quality in analytical way.

The empirical case represents one exported master's degree programme in teacher education that was implemented in Indonesia between the years 2016 and 2017 in collaboration between the Indonesian Yayasan Sukma Foundation and the Faculty of Education, University of Tampere, Finland. The focus of the Sukma Foundation's activity is education and the foundation owns three comprehensive schools in the Aceh region: Bireun, Pidie and Lhokseumawe. The contract for the master's degree programme was negotiated by Finland University Ltd., which is a consortium focused on marketing education export services and owned by the University of Tampere, University of Turku, University of Eastern Finland and Åbo Akademi.

The facilities were provided by the Sukma school in Bireuen, where students and teachers stayed. Students of the programme were teachers from Sukma schools, holding a bachelor's degree from an Indonesian university. Nearly all teachers of the programme were from the University of Tampere, though in a few cases, teachers were from other Finnish universities. Teachers stayed one week in Bireuen approximately once per month, and during that week, lectures took place. Between the intensive weeks, students had independent assignments. Also, students had a 6-week visit to Finland in the spring term of 2017. The aim of the Finland visit was to give students an opportunity to carry out observation in the Finnish comprehensive school and complete courses at the University of Tampere. 
The master's degree programme in teacher education was one of the first Finnish degree programmes organized abroad. Moreover, providing a foreign university degree programme in Indonesia was equally significant since Indonesia had traditionally had a rather strict policy towards foreign universities (see OECD 2015). Therefore, this paper raises two aspects. Firstly, this analysis reflects the education export action encouraged by the national higher education policymakers in Finland to improve HEIs' activity in the global educational market. Secondly, this analysis reflects the development of the Aceh region after natural disasters, where education has been one of the key political actions (Widyanto 2017). Accordingly, the paper describes the national educational policy objectives of Indonesia as a practical example of internationalization efforts in education and the improvement of teacher training (OECD 2015).

The empirical data consist of 16 semi-structured interviews done in Indonesia and in Finland between November 2016 and June 2017. Interviews were conducted in Finnish and in English, and the average duration of the interviews was $45 \mathrm{~min}$. Altogether, eight interview participants represented students, both female and male. Likewise, eight participants represented staff involved in the exported master's degree programme, both teaching and non-teaching staff, male and female. Student interviews took place in Indonesia in November 2016, while the interviews concerning teachers and staff members were conducted in Finland between January and June 2017. The selection of the interviewees was guided by the snowball method.

The semi-structured interviews consisted of four themes: expectation, personal experiences, important aspects and improvement ideas. The themes were stressed in the interviews by taking into account the situation; each interview was a unique social interaction depended on interview location, language used and whether the interviewee and the interviewer knew each other well in advance. Especially in the latter cases, the interviewer followed the interview template rather loosely and the interview process was not implemented strictly according to the plan. Also, each of the interviewees described their experiences from their own perspective; in the student interviews, both expectations and implementations were mentioned equally whereas staff members described especially the implementation phase related to their personal duties in the programme.

The transcribed interviews were analysed by applying qualitative content analysis. The analysis was conducted for both groups (students and staff members) as a separate process as it was considered to strengthen anonymity, though in cases where a certain factor was clearly stressed by a participant holding a teacher position, the term 'teacher' was used. In this stage, the focus was especially on the following research questions: what factors describe the quality of education (RQ1)? And what conventions steer the identified quality factors (RQ2)? Implicitly, the analysis included cross-group comparisons, and therefore, the analysis also indicated the differences and similarities between the students and the staff members. The qualitative content analysis consisted of the following aspects (Elo and Kyngäs 2008; Graneheim and Lundman 2004):

- Reading the interview transcripts several times and making sense of the data

- Coding the meaning units, which in this analysis, consist of sentences that refer to a certain meaning, such as 'benefits to Sukma schools'

- Categorizing the meaning units by identifying the similarities and differences

- Generating the main categories by abstraction

The process of the analysis followed the hermeneutic circle, supported by abductive logic. Abductive logic refers here to the researchers' pre-understanding of the research topic and the theoretical framework, which in principle impacted the researchers' interpretation of the empirical 
data (Elo and Kyngäs 2008). However, the researchers were not aiming to identify meaning units by relying only on gained pre-understanding based on the researchers' involvement in the master's programme ${ }^{2}$ rather the analysis and construction of the theoretical framework was done in parallel, by indicating the meaningful aspects that were identified from the empirical data and by giving them a theoretical frame (Paavola 2004). In this way, the theoretical framework, data analysis and writing of the research report were all embedded in previous understanding and the meaningful aspects were combined to allow more solid construction of the research topic. As an example, researchers' pre-understanding included the assumption that one core element of the programme is based on the Finnish approach to research-based teacher education. However, in the analysis, it became apparent that the Finnish approach to pedagogy-required thematic localisation, whereby the local purposes of the programme (the development of Sukma schools) had equal importance with research-based teacher training.

\section{Findings}

In this paper, the findings are presented in two groups, students and staff, as this allows more specific reporting of findings. An interviewee in this paper is referred to as a participant or, in the case of a group-related aspect, as a student or staff member, as we consider these terms to refer to a low-hierarchical power relationship between the participants and the researchers (Karnieli-Miller et al. 2009). In the case of quotes, the participants' are referred to as participant $1(\mathrm{P} 1)$ etc. to ensure anonymity. The quotes that were originally presented in Finnish have been translated into English, and the original transcriptions are added in the footnotes. The quotes have been chosen to demonstrate the key findings and to provide readers with the possibility of accessing the empirical data.

The group-specific findings are presented through the themes that were emphasized by the participants during the analysis process in relation to the research questions; the guiding principle of the theme identification is therefore based on the original research task (c.f. Elo and Kyngäs 2008). Nevertheless, as typical for qualitative research, the identification sharpened during the stages of the analysis process. In general, the results of this analysis emphasize the students' and staff members' commitment to the exported Finnish teacher education programme, which was considered an opportunity for personal and professional development. In this respect, Finnish education provided an opportunity for career development, the possibility to be part of the Finnish PISA success. Also, participants highlighted the importance of a common good; education was considered to support the development of Sukma schools and the Aceh region. These factors represent one successful outcome of the exported programme. The notion of the common good was especially emphasized by the students. During the analysis process, the notion became also the starting point for the other themes identified from the student interviews. On the other hand, the participants stressed the projectoriented nature of the exported programme, and comparability of the gained competences between the exported education and education organized in Finland. These factors described the challenges of education export implementation. One challenge was to make the courses to fit better for the local purposes but also maintain the Finnish approach to teacher education.

\footnotetext{
${ }^{2}$ The personal involvement by Juusola included one week of fieldwork in Indonesia in November 2016 and participation in events related to the programme in Finland. The teaching experiences of a senior lecturer Räihä included two months of lecturing and supervising in Indonesia in 2016-2017.
} 
This localizing challenge was stressed in nearly all staff members representing one of the core elements describing quality from the perspective of staff. As Table 2 shows, the identified factors were further turned into quality conventions by applying convention theory (CT) indicating the plurality of the underlying logics in a different sociocultural context.

\section{Students}

According to the students, the main success factors in this programme relate to students' personal commitment, supportive learning environment, education for the community good and Finnish education as a promise of something better (see Table 3 at the end of the chapter). Especially, personal commitment to professional development was raised by every student. For them, it indicated high motivation to gain a new perspective on teaching. This was based on the experiences gained from the assignments and from the Finnish case examples provided. New aspects were seen as valuable to both students themselves and pupils of Sukma schools. From the CT perspective, students' personal commitment relies on the inspiration (as new ideas) that supported the professional-academic conventions (as ability to apply a theoretical and methodological perspective in teaching).

Supportive learning environment, as indicated in the encouragement given by the teachers, referred to an open and dialectic teacher-student relationship especially with the permanently involved teachers visiting Indonesia several times. This enhanced students' learning process as students thought that the teachers were sincerely willing to support their learning and as students they were able to criticize and express their opinions freely. This was pivotal in the situation where students felt pressure to accomplish the programme successfully within the given time frame. Supportive learning environment refers to an interpersonal convention that stresses personal and familiar interaction. As one student pointed out:

And they [teachers] give us such good motivation. And then positive feedback and it makes me more confident. (Participant 1)

Accordingly, students wanted to share their knowledge with the other Sukma teachers that were not participating in the programme. Thus, learning and studying were seen as beneficial

Table 2 Characteristics of the quality conventions in this study (c.f. Boltanski and Chiapello 2005; Boltanski and Thévenot 2006; Storper and Salais 1997)

\begin{tabular}{|c|c|c|}
\hline Quality convention & Higher common principle & Characteristic \\
\hline Inspiration & Creativeness, enthusiasm & High motivation, new ideas \\
\hline Domestic & Responsibility, traditions & $\begin{array}{l}\text { Local traditions (in Indonesia/in Finland), } \\
\text { commitment to the local community }\end{array}$ \\
\hline Fame & Recognition; renown in public & Good reputation of Finnish education \\
\hline Civic & Collectiveness & Valuable in society; societal impact \\
\hline Market & Competition & Ability to respond to clients' needs \\
\hline Industrial & Effectiveness, productivity & Quality standards, effectiveness \\
\hline Academic & $\begin{array}{l}\text { Creating new knowledge based } \\
\text { on scientific standards }\end{array}$ & $\begin{array}{l}\text { Research-based teacher education, ability to apply a } \\
\text { research approach in teaching and studying }\end{array}$ \\
\hline Professional & $\begin{array}{l}\text { Knowledge and competence } \\
\text { based on expertise }\end{array}$ & Being highly expert in teaching (in practice) \\
\hline Interpersonal & Personal relations & $\begin{array}{l}\text { Interpersonal contacts among teachers and students; } \\
\text { providers and clients }\end{array}$ \\
\hline Project-oriented & Networking, being active & Ability to participate in education export activities \\
\hline
\end{tabular}


Table 3 Summary of the key factors and quality conventions

\begin{tabular}{lll}
\hline Participants & Factor & Quality convention \\
\hline \multirow{2}{*}{ Students } & Personal commitment & Inspiration, professional-academic \\
& Supportive learning environment & Interpersonal \\
& Education for the community good & Domestic-civic \\
& Finnish education as a promise of something better & Fame \\
Staff members & Professional commitment & Professional-inspiration, project-oriented \\
& Finnish approach to teacher education & Domestic, professional-academic \\
& Education for the common good & Civic-domestic \\
\hline
\end{tabular}

to the Sukma community. Studying in this respect was not only an individual choice, but also an effort for the whole community. Likewise, students considered it valuable that they had the possibility to improve the organizational development of Sukma schools and do something good for the Aceh region. Also, students emphasized that Sukma schools could become national 'example schools' and they could thus improve educational development not only in Aceh, but also in Indonesia as a whole. This kind of notion stresses the domestic-civic convention where education is seen as valuable across the base of the community.

However, personal commitment and teacher-student relationships in some respects clashed with the students' academic background. This refers to domestic convention, which includes traditions as a higher common principle. As one of the participants stated:

They (teachers in this programme) encourage us to do our best. So, it is also a new paradigm for me. Because most of the teachers and lecturers in Indonesia, most of them yes, some of them maybe they, they encourage the student. But some of them they only justify and judge the student in advance. So, it will discourage the students from doing their best (Participant 2).

In this programme, Finnish education was seen as a promise of something better. The reputation of Finland as an educational country and its success in the PISA study raised students' curiosity about and trust in the programme. Students described Finnish education as 'the best in the world', and they felt that having the possibility to gain a Finnish master's degree is a unique experience that supports personal development and Sukma school improvement. Thus, the fame convention convinced the students of the reliability of the programme especially at the beginning and increased motivation to participate in the programme. However, the reception of the programme was not wholly unreserved. One concern was the fact that the programme included distance learning and the programme was conducted in Indonesia, not in Finland. This was seen to weaken the academic atmosphere even though the permanent and qualified teachers further ensured reliability. In this respect, students appreciated personal contact with the Finnish teachers, and thus, after the programme was started, the fame convention was in some respects replaced by the interpersonal convention by increasing the students' confidence in the programme. However, the students were uncertain about the comparability of the qualifications. As one participant stressed:

Because in fact we will have, for example, we will have an MA degree from Tampere which is from Finland, theoretically we should have the same competence as the other students that take a degree in Finland. So, if we cannot match it up, there will be a problem then (Participant 5). 
Similarly, studying in a foreign language and the programme's intensity caused students concern. Especially, the pressures relating to the master's thesis were a topical issue during the interviews. While thesis concerns may be typical of any student, in this study, the comparability of the qualification (as comparable standards) and the intensity of studying (effectiveness) represent the industrial convention. As such, it reflects the rapid schedule for the implementation of the programme, which is based on the industrial convention (as effectiveness) and the market convention (as ability to respond to the client's need).

One issue in this programme was also the local tutors and their role in supporting students' ability to study in English and helping them to localize the new knowledge. Based on the participants' descriptions and personal observation, it seemed that local tutors were not necessarily fully aware of the principles of the Finnish education system or Finnish academic culture, which tends to emphasize a dialogic approach and avoids using standardized tests. This caused students uncertainty as local tutors tried to support them, especially with their master's thesis, by relying on their own personal academic experiences gained outside Indonesia (such as in the UK), but not in Finland. Therefore, the domestic convention was challenged by professional-academic and inspiration conventions.

\section{Staff}

For staff, the main factors describing the quality of education were participants' professional commitment, the Finnish approach to teacher education and education for the common good (see Table 3). Professional commitment related to participants' genuine interest in working in education export projects and they saw it as a possible career option in the future. Accordingly, participating in the exported programme required the possibility to work intensively despite other work duties. Participants also highlighted the ability to adapt to long travel times and a different climate and sociocultural environment. In addition, personal motivation to 'throw oneself into the programme', as one participant stressed, was important. Commitment to the programme and willingness to continue to work in education export projects refer to professional and inspiration conventions that set the frames for professional development, but also to the project-oriented convention as the ability to work intensively abroad while there are other duties at home.

The teachers emphasized that one of the key factors of this programme was research-based Finnish teacher education based on a scientific and dialogic approach, but also teachers' autonomy and ability to localize the lectures. Particularly, supporting students' personal and professional development by fostering trust-based dialogue and modifying the course to fit the local context were stressed. From the perspective of CT, these aspects refer to the academicprofessional conventions, where strengthening teacher identity is supported by research-based teacher education. The curricula of this programme were localized to better suit the contextual purposes referring to domestic convention. Localizing the courses may have required any ongoing concerns to be appropriately balanced with the domestic convention (as localizing the courses and as maintaining the Finnish approach to teacher education), academic convention (as a research-oriented approach) and professional convention (as supporting the students' expertise in teaching). Participants also stressed the dialogic perspective as an important quality factor by emphasizing concerns about using a temporary workforce or fostering the scalability of education export projects. As one participant stated:

Those who buy these services, education services, of course, they also want as much as possible to get their share of this sort of existing education know-how. Which means, if, 
for example, an agreement is made with the faculty of education, then those people who are in this faculty of education, who are part of this sort of success, then they also have to be involved in teaching (in education export projects) as well ${ }^{3}$ (Participant 10 ).

From the CT perspective, relying on something familiar and traditional that increases trust indicates the domestic convention, which in this case refers to the Finnish approach to teacher education. However, considering Finland as a country for educational know-how is primarily supported by the fame convention (as being recognized in public). Also, participants stressed that they are not importing any ready-made product. According to them, the main focus in education export activities is on knowledge transformation, which is an ongoing process. As one participant commented:

We are offering participation in certain processes and we try to start to launch these certain processes in these people and in these communities to which we go. And what does that process, or those processes produce? That is just somewhere else. We don't know about that. It can produce ... it produces meanings. That much we do know. And it should produce new meanings. But what will be constructed from these meanings? It's an interesting question ${ }^{4}$ (Participant 16)

According to the participants, context sensitivity related to support for education for the common good. In this case, the common good was focusing on development of Sukma schools by localizing the curricula, but it was also connected with the interaction among Sukma representatives (students and representatives from the Sukma Foundation). According to the participants, understanding different cultural practicalities, such as the role of religion, was important and almost self-evidently to be taken into account during the programme implementation. Also, the participants stressed the need to understand the position of education in Indonesian society. Thus, participants saw it as important to gain shared understanding with the Sukma representatives of what the exported master's degree really means in the Indonesian context. These aspects were primarily based on the civic convention that stresses community basis and societal impact, and were in that sense one of the core elements in this programme. Context-sensitivity referred also to the domestic convention that indicates local cultural practicalities, values and the position of teacher education in Aceh and in Indonesia.

Context sensitivity also included legislative issues and interaction with the other local actors. For example, due to Indonesian taxation practices and efforts to avoid tax evasion in Indonesia, face-to-face lectures were given during the intensive weeks. Also, before its implementation, the programme was presented to representatives of the local community (such as representatives of the universities of the Aceh region), as it was seen as important that the programme had community approval. Such issues reflect the strong position of the domestic convention in terms of justifying the programme implementation among the local community.

\footnotetext{
${ }^{3}$ Original transcription: 'Nämä jotka ostaa palveluja, tätä koulutusta, niin he tietenkin haluaa myöskin osansa meidän ikään kuin olemassa olevasta koulutusosaamisesta. Joka tarkoittaa, että jos esimerkiksi tehdään sopimus kasvatustieteen tiedekunnan kanssa, niin silloin näitä henkilöitä, jotka ovat tätä kasvatustieteen tiedekuntaa, jotka on osa tätä tavallaan menestystä, niin heidän pitää olla mukana siinä opetustoimessa'.

${ }^{4}$ Original transcription: 'Me tarjotaan osallisuutta tiettyihin prosesseihin ja koitetaan käynnistää ne tietyt prosessit näissä ihmisissä ja näissä yhteisöissä, joihin me mennään. Ja mitä se tuottaa se prosessi, tai ne prosessit? Se on ihan jossaki muualla. Me ei tiedetä siitä. Se voi tuottaa... Se tuottaa merkityksiä. Me tiedetään se. Ja sen pitäs tuottaa uusia merkityksiä. Mut mitä niist merkityksistä kootaan? Se on kiinnostava kysymys'.
} 
Participants also mentioned ethical concerns that were related to the commercialization of education. In this case, the participants considered the relationship between education exports and universities' core duties as well as the terms under which education export activity is implemented. Participants, however, also mentioned that education export activities that support local development are having a societal impact and are the 'third mission of universities', and are therefore valuable and justified. This refers to the importance of the civic convention that legitimates the education export activities not only in Indonesia but also in Finland.

Moreover, implementing an exported degree programme abroad is a fairly recent activity for the Faculty of Education and for Finland. According to the participants, this requires specific attention to curricula design and the faculty's human resource policies. Especially, ensuring appropriate human resources in terms of having a more flexible annual teaching plan was mentioned. This reflects the increasing dominance of the project-oriented convention, which however conflicts with the established practices indicating the domestic convention.

\section{Conclusion}

The findings show that the quality of education is perceived in terms of the diverse factors related to the needs of the student group and expectations of the client, but also of the providers' priorities as to what is essential in degree-based education. As an example, participants stressed the development of the Sukma schools and trust-based cooperation among the different actors, but also the research-based approach to Finnish teacher education, thus highlighting the dynamics of social interaction when implementing education export. These considerations emphasize the professional-academic convention that, together with the civic-domestic convention, influenced the content of the educational programme through personal interaction. This may indicate that a successful implementation of education export activities is not primarily based on the market convention, i.e. provider's ability to respond to the client's need. Instead the quality of education in education export activities seems to include multiple conventions that illustrate the recipient's aims of gaining something better and the provider's ability to balance the different educational traditions without losing contact with their own discipline, university and national starting points.

Participants' notions about the good reputation of Finnish education refer to the fame convention where what matters the most is being recognized in public. Students' awareness of Finland as a country of superior PISA performance increased trust in the novice programme. However, Finnish teachers needed to justify this good reputation in practice when giving lectures and student guidance. This stressed the teacher's role in fostering and maintaining academic quality (Altbach and Knight 2007; Bovill et al. 2015). On the one hand, the success story of Finnish education may boost Finnish education exporters in the global fame competition, and fill the Finnish gap of lacking any specific internationally highly ranked universities. On the other hand, national reputation is a complex and narrow way of guaranteeing quality of education or setting criteria for academic standards. However, based on previous studies, the prestige of the institution seems to be embedded in the decision of students, and of their families, when choosing an appropriate place of study (Marginson 2006). The conventional clash became apparent in the circumstances of implementation, which were dominated by the market, industrial and domestic conventions; the implementation of the programme was partially organized in terms of efficiency, ability to react to client needs and local legislation. 
As an example, taxation practicalities in Indonesia set the timeframe for face-to-face lectures and efforts to respond to the Sukma's needs had an impact on the programme's relatively fast implementation. In general, these kinds of notions refer to the impact of market-driven forces (Marginson 2006; Slaughter and Leslie 1997) that may impact on a narrow implementation timeframe (Bovill et al. 2015). Also, teachers had to balance their teaching and researching in Finland with giving lectures abroad, which reflected the project-oriented convention. However, the latter was not only a teacher's personal choice, but also an expectation by the Faculty of Education, stressing the project-oriented convention.

Quality of education and quality assurance in education export implementation can include more uncertainties compared with quality of education and quality assurance in familiar social, political, economic and legal frameworks (Borgos 2013). Thus, the established process description and institutional principles are not necessarily applicable as such. As stated in previous studies, fragmented stakeholder groups (Altbach and Knight 2007) and cultural and political variety of education export project locations may impact on the quality of learning opportunities (Sharp 2017). Moreover, the comparability of qualifications may lead to a demand to stress the importance of clearly defined academic standards (Sharp 2017). At the institutional level, this may lead to twofold, partly clashing demands: existing institutional practices, such as designing teachers' working plans to be flexible enough to consider the requirements of the implementations, and furthermore, the qualification and management of the implementation provided should be sufficiently comparable with domestic and international activities.

In general, situational uncertainties and information asymmetry, as well as institutional incompleteness, may lead to a multistage process where orders of worth are reorganized several times. Over a longer term, certain conventions may become forms (investment in forms) that can refer to standardized criteria for education export activity at institutional and national levels. Though, investment in forms as such is susceptible to criticism and can be challenged (Blokker and Brighenti 2011). However, without the national quality criteria for education export activities, each HEI is balancing the conflicting demands independently and investment in forms happens only at the institutional level. This may not provide a robust regime for gaining national legitimacy for education export activities in terms of public accountability which is often embedded in the national external quality assurance (c.f. Leihy and Salazar 2017).

While this study enabled us to consider quality of education from the pragmatic perspective, the convention theoretical (CT) approach includes a certain limitation. On the one hand, the underlying conventions indicated the values and logics of the quality factors, although the connection with convention and institution is not extensively explored. One possibility could be to supplement the theoretical framework with the institutional work approach that could foster the actor's role of maintaining and changing the institution (Lawrence et al. 2011). On the other hand, higher education offers a comprehensive research topic for CT applications. As an example, when considering education export implementations, the contradictions were not only between the conventions but also within the conventions. This became apparent in the domestic convention, which referred both to the Finnish educational tradition and Indonesian educational tradition, thus including the potential internal clash between these two different traditions. One theoretical explanation may be that conventional compromises are possible also inside the convention - not only between conventions, although to clarify this, it would be necessarily to conduct a longitudinal study and/or have more empirical cases preferably from outside western educational tradition. 
Funding This work was supported by the Finnish Cultural Foundation (grant number 00180433).

Open Access This article is distributed under the terms of the Creative Commons Attribution 4.0 International License (http://creativecommons.org/licenses/by/4.0/), which permits unrestricted use, distribution, and reproduction in any medium, provided you give appropriate credit to the original author(s) and the source, provide a link to the Creative Commons license, and indicate if changes were made.

\section{References}

Altbach, P., \& Knight, J. (2007). The internationalization of higher education: Motivations and realities. Journal of Studies in International Education, 11(3), 290-305.

Biggart, N. W., \& Beamish, T. D. (2003). The economic sociology of conventions: Habit, custom, practice, and routine in market order. Annual Review of Sociology, 29, 443-464.

Blokker, P., \& Brighenti, A. (2011). An interview with Laurent Thévenot: On engagement, critique, commonality, and power. European Journal of Social Theory, 14(3), 383-400. https://doi.org/10.1177 $/ 1368431011412351$.

Boltanski, L., \& Chiapello, E. (2005). The new spirit of capitalism. International Journal of Politics, Culture, and Society, 18(3/4), 161-188. https://doi.org/10.1007/s10767-006-9006-9.

Boltanski, L., \& Thévenot, L. (2006). On justification: Economies of worth. Princeton (N.J.): Princeton University Press.

Borgos, J. E. (2013). Using principal-agent theory as a framework for analysis in evaluating the multiple stakeholders involved in the accreditation and quality assurance of international medical branch campuses. Quality in Higher Education, 19(2), 173-190. https://doi.org/10.1080/13538322.2013.805068.

Bovill, C., Jordan, L., \& Watters, N. (2015). Transnational approaches to teaching and learning in higher education: Challenges and possible guiding principles. Teaching in Higher Education, 20(1), 12-23. https://doi.org/10.1080/13562517.2014.945162.

Coates, H., \& Mahat, M. (2014). Threshold quality parameters in hybrid higher education. Higher Education, 68(4), 577-590. https://doi.org/10.1007/s10734-014-9729-x.

Diaz-Bone, R., \& Salais, R. (2011). Economics of convention and the history of economies. Towards a transdisciplinary approach in economic history. Historical Social Research / Historische Sozialforschung, 36(4), 7-39.

Elo, S., \& Kyngäs, H. (2008). The qualitative content analysis process. Journal of Advanced Nursing, 62(1), 107-115. https://doi.org/10.1111/j.1365-2648.2007.04569.x.

FINEEC. (2015). Audit manual for the quality systems of higher education institutions 2015-2018 Finnish Education Evaluation Centre.

Friedland, R. \& Alford, R. (1991). Bringing society back in: Symbols, practices, and institutional contradictions in W. Powell \& P.DiMaggio (Eds.), The new institutionalism in organizational analysis, (pp. 232-266) Chicago: University of Chicago Press.

Graneheim, U. H., \& Lundman, B. (2004). Qualitative content analysis in nursing research: Concepts, procedures and measures to achieve trustworthiness doi:http://dx.doi.org.helios.uta.fi/10.1016/j.nedt.2003.10.001.

Greenwood, R., Raynard, M., Kodeih, F., Micelotta, E. R., \& Lounsbury, M. (2011). Institutional complexity and organizational responses. The Academy of Management Annals, 5(1), 317-371.

Harvey, L., \& Green, D. (1993). Defining quality. Assessment \& Evaluation in Higher Education, $18(1), 9$.

Juusola, H., \& Räihä, P. (2018). Exploring teaching staff's experiences of implementing a Finnish master's degree programme in teacher education in Indonesia. Research in Comparative and International Education, 13(2), 342-357.

Karnieli-Miller, O., Strier, R., \& Pessach, L. (2009). Power relations in qualitative research. Qualitative Health Research, 19(2), 279-289. https://doi.org/10.1177/1049732308329306.

Kinser, K. (2011). Multinational quality assurance. New Directions for Higher Education, 155, 53-64. https://doi.org/10.1002/he.444.

Knight, J. (2016). Transnational education remodeled. Journal of Studies in International Education, $20(1), 34$ 47. https://doi.org/10.1177/1028315315602927.

Lawrence, T., Suddaby, R., \& Leca, B. (2011). Institutional work: Refocusing institutional studies of organization. Journal of Management Inquiry, 20(1), 52-58.

Leihy, P., \& Salazar, J. M. (2017). Quality street: Encountering higher education's accountabilities. Quality in Higher Education, 23(1), 3. 
Leemann, R. J. (2018). Free movement of people and capital and the standard of transnational academic mobility: Principles of governance in the European research area. European Educational Research Journal, , 147490411877394. https://doi.org/10.1177/1474904118773946.

Marginson, S. (2006). Dynamics of national and global competition in higher education. Higher Education, 52(1), 1-39. https://doi.org/10.1007/s10734-004-7649-x.

OECD. (2015). Education in Indonesia: Rising to the challenge. Paris: OECD. https://doi.org/10.1787 /9789264230750-en.

Paavola, S. (2004). Abduction as a logic and methodology of discovery: The importance of strategies. Foundations of Science, 9(3), 267-283. https://doi.org/10.1023/B:FODA.0000042843.48932.25.

Ponte, S. (2009). Governing through quality: Conventions and supply relations in the value chain for South African wine. Sociologia Ruralis, 49(3), 236-257. https://doi.org/10.1111/j.1467-9523.2009.00484.x.

Pyvis, D. (2011). The need for context-sensitive measures of educational quality in transnational higher education. Teaching in Higher Education, 16(6), 733-744. https://doi.org/10.1080/13562517.2011.570436.

Schatz, M. (2016). Education as Finland's hottest export?: A multi-faceted case study on Finnish national education export policies Helsingin yliopisto.

Segers, M., \& Dochy, F. (1996). Quality assurance in higher education: Theoretical considerations and empirical evidence. Studies in Educational Evaluation, 22(2), 115-137. doi:https://doi.org/10.1016/0191-491X(96 00007-7.

Sharp, K. (2017). The distinction between academic standards and quality: Implications for transnational higher education. Quality in Higher Education, 23(2), 138-152. https://doi.org/10.1080/13538322.2017.1356615.

Silva, D., Moraes, G., Makiya, I., \& Cesar, F. (2017). Measurement of perceived service quality in higher education institutions: A review of HEdPERF scale use. Quality Assurance in Education, 25(4), 415-439. https://doi.org/10.1108/QAE-10-2016-0058.

Slaughter, S., \& Leslie, L. L. (1997). Academic capitalism: Politics, policies, and the entrepreneurial university. Baltimore: The Johns Hopkins University Press.

Slaughter, S., \& Rhoades, G. (2004). Academic capitalism and the new economy: Markets, state, and higher education. Baltimore: Johns Hopkins University Press.

Storper, M., \& Salais, R. (1997). Worlds of production: The action frameworks of the economy. Cambridge (Mass.): Harvard University Press.

Thévenot, L. (1984). Rules and implements: Investment in forms. Information (International Social Science Council), 23(1), 1-45. https://doi.org/10.1177/053901884023001001.

Widyanto, A. (2017). Reformulating strategies to develop democratization through civic education in Aceh. Ulumuna, 21(1), 33-56. https://doi.org/10.20414/ujis.v21i1.1179.

Publisher's note Springer Nature remains neutral with regard to jurisdictional claims in published maps and institutional affiliations. 